\title{
ERRATUM $^{1}$
}

\author{
KARL W. SCHWARZ \\ Evangeličanska teološka fakulteta Univerze na Dunaju, Dunaj \\ karl.schwarz@univie.ac.at
}

V Enciklopediji slovenske kulturne zgodovine na Koroškem: od začetkov do leta 1942 (Enzyklopedie der slowenischen Kulturgeschichte in Kärnten/Koroška. Uredila Katja Sturm-Schnabl in Bojan-Ilija Schnabl. Dunaj: Bohlau Verlag, 2016) je tudi članek o Dalmatinovi Bibliji (zv. 1, str. $233 \mathrm{f}$ ), ki ga je podpisal Karl W. Schwarz. V članku avtor obravnava tudi izobraževalno pot Trubarjevega učenca Jurija Dalmatina (1547-1589) ter omeni njegov študij v Tübingenu, kjer je leta 1568 dosegel bakalaureat in bil 1569 promoviran za magistra. To akademsko pot mu je omogočil tako imenovani »Tiffernum«, štipendijski sklad slovenskega mecena Michaela Tiffernusa (1488/89-1586). Ta je bil po rodu s Kranjske: kot najdenček brez staršev je zrasel in bil vzgojen v Laškem/Tuffer. Študiral je na Dunaju, dosegel akademsko stopnjo magistra in delal kot vzgojitelj plemiških otrok: tako je leta 1526 postal njegov vzgajanec tudi princ Christoph von Württemberg (1515-1568), ki je živel na cesarskem dvoru pod skrbništvom Ferdinanda I., potem ko je njegov oče Ulrich von Württemberg izgubil vladarske pravice. Tiffernus je leta 1532 pomagal svojemu učencu pobegniti iz avstrijskega ujetništva. Ko je Christoph po očetovi smrti prevzel vladanje, ga je leta 1550 nagradil z visokim in vplivnim položajem vojvodovega svetovalca. Za zgodovino slovenske reformacije je postal pomemben prav s štipendijskim skladom »Tiffernum»

1 Karl W. Schwarz, član mednarodnega sosveta revije in avtor več prispevkov v njej, nas je zaprosil, da tudi v naši reviji objavimo njegov popravek in strokovno javnost opozorimo na neljubo napako. 
za nadarjene študente s Kranjske. Med njimi je bil v letih 1566-72 tudi Jurij (Georg) Dalmatin.

V omenjenem članku pa je sklad Tiffernum povezan z Augustom Tyfernusom, slovenskim humanistom in kanclerjem pri Svetem Štefanu na Dunaju (umrl 1535). Ta zavajajoča informacija ni avtorjeva, temveč je bila vnesena v članek od tretje roke pri zadnji redakciji besedila.

Ker sem bil mnogo let v prijateljskem stiku s tübingenskim teologom Christophom Weismannom (1940-2013), zelo dobro poznam njegovo študijo o humanistu Michaelu Tiffernu (»Mentor Herzogs Christoph und Mäzen des Tübinger Stifts, " v Wahrheit und Freiheit: 450-Jahre Evangelisches Stift in Tübingen, ur. Friedrich Hertel (Stuttgart: Calwer Verlag, 1986), 47-80) in študijo o njegovem skladu kot primeru spodbujanja mednarodnega študija v 16.stoletju (»Primus Truber und die Tübinger Tiffernstiftung, « v Ein Leben zwischen Laibach und Tübingen, ur. Rolf-Dieter Kluge (München: Otto Sagner, 1995), 414-26); leta 2011 sem ju upošteval v opombah o Michaelu Tiffernusu v prevodu knjige Jožeta Javorška Primož Trubar (iz slovenščine prevedla Richard Götz in Metka Wakounig, uvod in opombe Karl W. Schwarz (Klagenfurt/ Celovec: Wieser)).

Poleg tega je z življenjsko potjo Michaela Tiffernusa in njegovim skladom bralce seznanil Primož Simoniti, ko je pisal o humanizmu pri Slovencih (Humanismus bei den Slovenen: Slovenische Humanisten bis zur Mitte des 16. Jahrhunderts, Zentraleuropa-Studien, Band 11, ur. Marija Wakounig, prev. Jože Wakounig (Dunaj: Verlag der Österreichischen Akademie der Wissenschaften, 2008), 250-55).

Zaželjeno bi bilo, da urednik in založba $\mathrm{v}$ ustrezni obliki opozorita na ta Erratum. 